ReVISTA de BIOLOGía TROPICAL

\title{
Variations in the geostrophic circulation pattern and thermohaline structure in the Southeast Central American Pacific
}

\author{
Carlos Brenes, Daniel Ballestero, Rosario Benavides, Juan Pablo Salazar, \& Gustavo Murillo \\ Laboratorio de Oceanografía, Universidad Nacional, Apdo. 86-3000 Heredia, Costa Rica; cbrenes.una@gmail.com, \\ daballest@gmail.com,rbmorera@gmail.com,jps_139@yahoo.com,gamz002@gmail.com
}

Received 23-IV-2014. Corrected 12-V-2015. Accepted 09-VII-2015.

\begin{abstract}
This study was conducted in the southeast region of the Central American Pacific, an area of great oceanographic importance due to the presence of various upwelling phenomena and the direct influence of the ENSO on its waters. Its main objective was to contribute to the knowledge of the main factors that modulate the regional dynamics. We describe the geostrophic circulation and thermohaline features along two transects obtained in October 2010 and March 2011, one from Costa Rica at (84 54' W - $\left.9^{\circ} 37^{\prime} \mathrm{N}\right)$ to the SW of Cocos Island at $\left(88^{\circ} 19^{\prime} \mathrm{W}-3^{\circ} 06^{\prime} \mathrm{N}\right)$, and the second oriented zonally across the island from $\left(88^{\circ} 14^{\prime} \mathrm{W}-5^{\circ} 33^{\prime} \mathrm{N}\right)$ to $\left(84^{\circ} 33^{\prime} \mathrm{W}-5^{\circ} 33^{\prime} \mathrm{N}\right)$. Surface temperatures ranged from $27^{\circ} \mathrm{C}$ to $29^{\circ} \mathrm{C}$ and a near isothermal layer, with an average thickness of $40 \mathrm{~m}$, was apparent above the thermocline centered at $60 \mathrm{~m}$. Surface salinities were between 32 and 32.8, typical values of the Tropical Surface Water. In both years, Cocos Island was located in a region of low surface salinities $(\sim 32)$. The salty core of the Subtropical Subsurface Water $(\sim 35)$ was located at an average depth of $150 \mathrm{~m}$. In October the circulation between Cocos Island and the continent was dominated by the presence of the North Equatorial Countercurrent (NECC), with speeds above $40 \mathrm{~cm} \mathrm{~s}^{-1}$ in the upper $50 \mathrm{~m}$ of the water column. No flow to the northwest near the coast that could be associated with the Costa Rica Coastal Current (CRCC) in October was observed. The Cocos Island was located in the center of a $150 \mathrm{~m}$ deep, $100 \mathrm{~km}$ diameter anticyclonic eddy, with surface speeds of $10 \mathrm{~cm} \mathrm{~s}^{-1}$ and $20 \mathrm{~cm} \mathrm{~s}^{-1}$. In March the study area was again dominated by an anticyclonic cell, with eastward flow between $50 \mathrm{~cm} \mathrm{~s}^{-1}$ and $60 \mathrm{~cm} \mathrm{~s}^{-1}$ located between $200 \mathrm{~km}$ north and $100 \mathrm{~km}$ south of the island. The southern end of this cell, with velocities between $10 \mathrm{~cm} \mathrm{~s}^{-1}$ and $50 \mathrm{~cm} \mathrm{~s}^{-1}$ to the northwest, was located $200 \mathrm{~km}$ south of Cocos Island. A flow to the NW near the edge of the continental shelf, consistent with the CRCC, was observed in May. Our study contributes to document the oceanography of the eastern end of the Equatorial Current System near the coast of Central America, where regional forcing modifies the zonal flow which prevails west of the study area. Rev. Biol. Trop. 64 (Suppl. 1): S121-S134. Epub 2016 February 01.
\end{abstract}

Keywords: Geostrophic circulation, North Equatorial Countercurrent, Cocos Island, water masses.

Circulation between the Equator and $10^{\circ}$ is well defined of the $110^{\circ} \mathrm{W}$ meridian (Wyrtki, 1965; 1966; Tsuchiya, 1975; Tsuchiya, \& Talley, 1998; Kessler, 2002; 2006), and consists of two currents flowing westwards: the South Equatorial Current (SEC) and the North Equatorial Current (NEC). Between them is the North Equatorial Countercurrent (NECC) (between $5^{\circ} \mathrm{N}$ and $10^{\circ} \mathrm{N}$ ). This surface current system is due to the distribution of trade winds and its convergence on the Intertropical Convergence Zone (ITCZ), seasonally changing with the north-south movement of the ITCZ, which is located in its southernmost (north) position in February-April (June-September) (Amador, Alfaro, Lizano, \& Magaña, 2006).

Between the $110^{\circ} \mathrm{W}$ meridian and the American Continent the surface flow pattern is not well known because of the effects associated with the proximity of the coast and the influence of the Continent on the trade wind field (Kessler, 2002). During the Northern Hemisphere's winter, the NECC disintegrates at around $110^{\circ} \mathrm{W}$, rotating and merging 
with the westward current system. During the northern summer, this current develops until it reaches areas close to the Central American coast, where it turns northwards, feeding the Costa Rica Coastal Current (CRCC). The cyclonic gyre of the NECC takes place around the Costa Rican Thermal Dome (CRTD), characterized by a rise of the thermocline centered at $\left(9^{\circ} \mathrm{N}-90^{\circ} \mathrm{W}\right)$. The evolution of the CRTD is closely related to the wind stress curl and the equatorial current system (Fiedler, 2002; Kessler, 2002; 2006).

The previous description of surface circulation and of the CRTD is based on analysis of historical data (surface temperature, temperature profiles, drift boats opportunity) and, more recently, from drifters and satellite data, including wind velocity based on scatterometers (Fiedler, 2002; Kessler, 2002; 2006; Chelton, Schlax, Freilich, \& Milling, 2004).

There are a very few direct observations made at a regional level, in particular near the coast or the CRTD area, to support and add new details to the previous descriptions. The recent work by Brenes, Lavín \& Mascarenhas (2008) describes the geostrophic circulation between the CRTD and Central America based on two oceanographic surveys carried out at the beginning of the 1990s.

The study of thermohaline properties and the current pattern in a transect between Costa Rica (Cabo Blanco) and Cocos Island (centered at $5^{\circ} 32^{\prime} \mathrm{N}-87^{\circ} 04^{\prime} \mathrm{W}$ ) is of particular interest for several reasons. Firstly, the NECC experiences a strong divergence in this zone originating two well-defined flows towards the northwest and the southeast (Wyrtki, 1965). Additionally, the study of the behavior of the CRCC can contribute to identify the area where the current originates. Finally, the results can be integrated into the regional dynamics of the Eastern Tropical Pacific (ETP) Ocean to characterize phenomena such as El Niño-Southern Oscillation (ENSO) and aspects associated with the CRTD (Díaz, \& Neshyba, 1983).

This study is intended to contribute to the knowledge of the regional oceanic dynamics in areas located in the southeast of the Central
American Pacific. Hydrographic data of two cruises were used to describe the field of geostrophic currents and the thermohaline properties of water masses, trying to provide support for results of recent investigations, and add details to aspects of scientific relevance, such as the behavior of the NECC when it reaches its eastern border, as well as its influence on Cocos Island.

\section{MATERIALS AND METHODS}

Temperature and salinity profiles were obtained in two oceanographic cruises made with the ship Undersea Hunter. The first was between October 2 and 10 of 2010, and the second was between March 26 and April 3 of 2011. These months were selected because in climatic and oceanographic terms the area studied shows important variations in the wind fields and oceanic currents between these times of year. In October the NECC is very well defined in the Cocos Island area, and in March the forcings of the Papagayo and Panamá jets prevail (Kessler, 2006). A Conductivity-Temperature-Depth (CTD) profiler model SB-19 plus was used to sample the water column in 35 stations throughout two transects; the first one with a northeast-southwest orientation (T-I), and the second one with a west-east orientation (T-II), having the Cocos Island as an intersection point (Fig. 1). In October samples were taken in only 32 stations, with the station to the farthest south in T-I being station 21, and T-II starting with station 22 at the western end, to end in station 32. Hydrographic stations, separated by 20 nautical miles $(37 \mathrm{~km})$ in order to obtain a good description of the main hydrographic characteristics and oceanic currents, attained depths of $480 \mathrm{~m}$. The spacing between stations in this study is well below the Rosbby radius of deformation calculated for the area (100-150 km and even larger to the south of Cocos Island) by Chelton, DeSzoeke, Schlax, Naggar \& Siwertz (1998).

Velocity fields were estimated using the geostrophic approximation based on temperature and salinity profiles, taking the maximum 

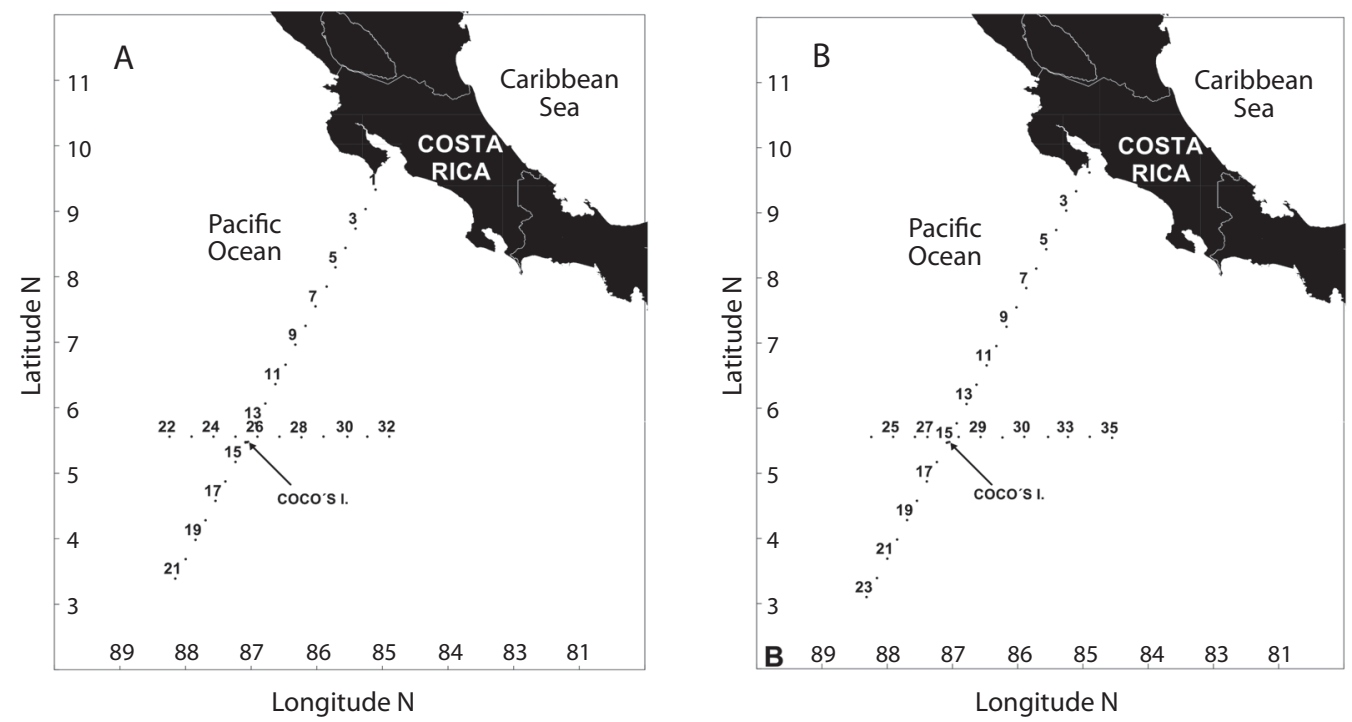

Fig. 1. Position of hydrographic stations in October 2010 (A) and March 2011 (B).

Fig. 1. Posición de las estaciones hidrográficas en octubre 2010 (A) y marzo 2011 (B).

common depth between pairs of stations as the level of null motion. The geostrophic model calculates the velocity at the midpoint between two stations, and its direction is perpendicular to the orientation of the transect, so that the flows determined in our study were directed to the NW or SE in the first transect, and to the N or $\mathrm{S}$ in the second transect. The reference level used for most stations was located between $400 \mathrm{~m}$ and $450 \mathrm{~m}$, similar to values used in previous studies of geostrophic currents in the region (Kessler, 2002; 2006, Brenes, 1983), but a small number hydrographic profiles, particularly numbers 7 to 10 in October 2010, only attained depths around $300 \mathrm{~m}$. Although the main features of upper layer geostrophic velocities are captured, the limited depths attained in this study impair the analysis to estimate volume transports with the available data.

Using data from AVISO (http:/www.aviso. oceanobs.com), maps of weekly averages of the surface geostrophic velocity vector, in $\mathrm{cms}^{-1}$, were produced with a spatial resolution of $1 / 4$ of a degree of latitude and of longitude. The daily $\mathrm{u}$ and $\mathrm{v}$ components of the surface geostrophic velocity were obtained from the AVISO Merged, Delayed-Time products derived from the Map of Absolute Dynamic Topography (MADT) to produce weekly maps of geostrophic velocity vectors. The product used in this study includes altimetric data from all satellites available on the dates of observation (Jason-1, Jason-2, Cryosat-2, Saral/AltiKa).

\section{RESULTS}

The temperature section in transect I during the October cruise (Fig. 2A) shows an almost isothermal warm, $27^{\circ} \mathrm{C}$ surface layer above the thermocline extending to a depth of $40 \mathrm{~m}$. The North end of the transect, over the continental shelf (stations 1 and 2), shows a 20-m thick surface isothermal layer. The thermocline, centered at the $20^{\circ} \mathrm{C}$ isotherm, is located at a depth of $60 \mathrm{~m}$ in the open sea, rising towards the continent starting in station 9.

In the October zonal transect (T-II), the thermocline is also located at $60 \mathrm{~m}$ and the surface layer reaches a depth of $30 \mathrm{~m}$ (Fig. 2C). In the west end of transect II, specifically in station 23 , a rise of the isotherms is observed from a depth of $400 \mathrm{~m}$, uplifting the thermocline to a depth of $25 \mathrm{~m}$ while the surface layer 

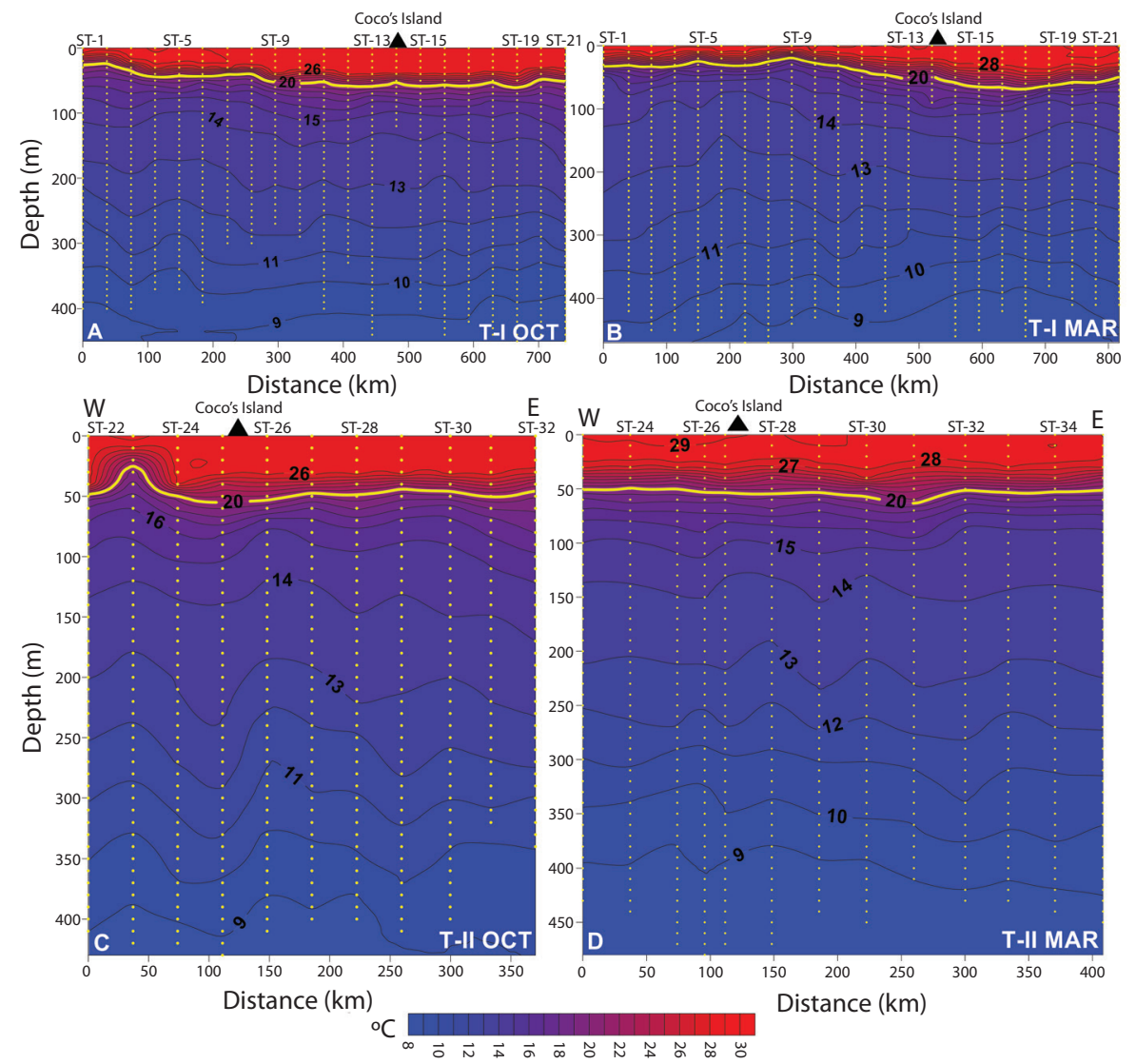

Fig. 2. Vertical distribution of temperature $\left({ }^{\circ} \mathrm{C}\right.$ ) for the months of October 2010 (A) Transect I, (C) Transect II, and March 2011 (B) Transect I, (D) Transect II. Yellow line indicates the position of the thermocline $\left(20^{\circ} \mathrm{C}\right.$ isotherm).

Fig. 2. Distribuciones verticales de temperatura $\left({ }^{\circ} \mathrm{C}\right)$ para octubre 2010 (A) Transecto I y (C) Transecto II, y marzo 2011 (B) Transecto I y (D) Transecto II. Línea amarilla define la posición de la termoclina (isoterma $20^{\circ} \mathrm{C}$ ).

is reduced to a thickness of $10 \mathrm{~m}$. This structure in the shape of a dome, on a $60 \mathrm{~km}$ horizontal scale, seems to be the hydrographic expression associated with a cyclonic eddy. The feature is present in both the up and down CTD casts but does not show in altimetry data. Contemporary SST satellite data were not available for the dates and locations of the cruise to confirm the presence of this eddy, a limitation prevalent during this time of year for the area.

During the second cruise (March 2011), the surface layer in transect I showed temperatures above $28^{\circ} \mathrm{C}$ (Fig. 2B). Its thickness was reduced to $20 \mathrm{~m}$ in most of the region between the continent and Cocos Island, reaching $40 \mathrm{~m}$ at the south of the Island (stations 18 and 19).
The behavior of the thermocline observed in both months is the same, where the $20^{\circ} \mathrm{C}$ isotherm is located closer to the surface $(30 \mathrm{~m})$ at the north end and deeper at the south end $(\sim 60 \mathrm{~m})$. In transect II the thickness of the surface isothermal layer is $30 \mathrm{~m}$ throughout the region (Fig. 2D), while the thermocline is located at a depth of $50 \mathrm{~m}$.

In October, less saline surface waters in transect I were observed in the region close to the continent between stations 1 and 5 (Fig. $3 \mathrm{~A}$ ), with values lower than 32. A well-defined halocline around $40 \mathrm{~m}$ deep separates surface waters from the core of high salinity Subsurface Subtropical Water (SSW) $(\mathrm{S}>34.8)$. Salinity in the first $30 \mathrm{~m}$ of the water column is lower than 

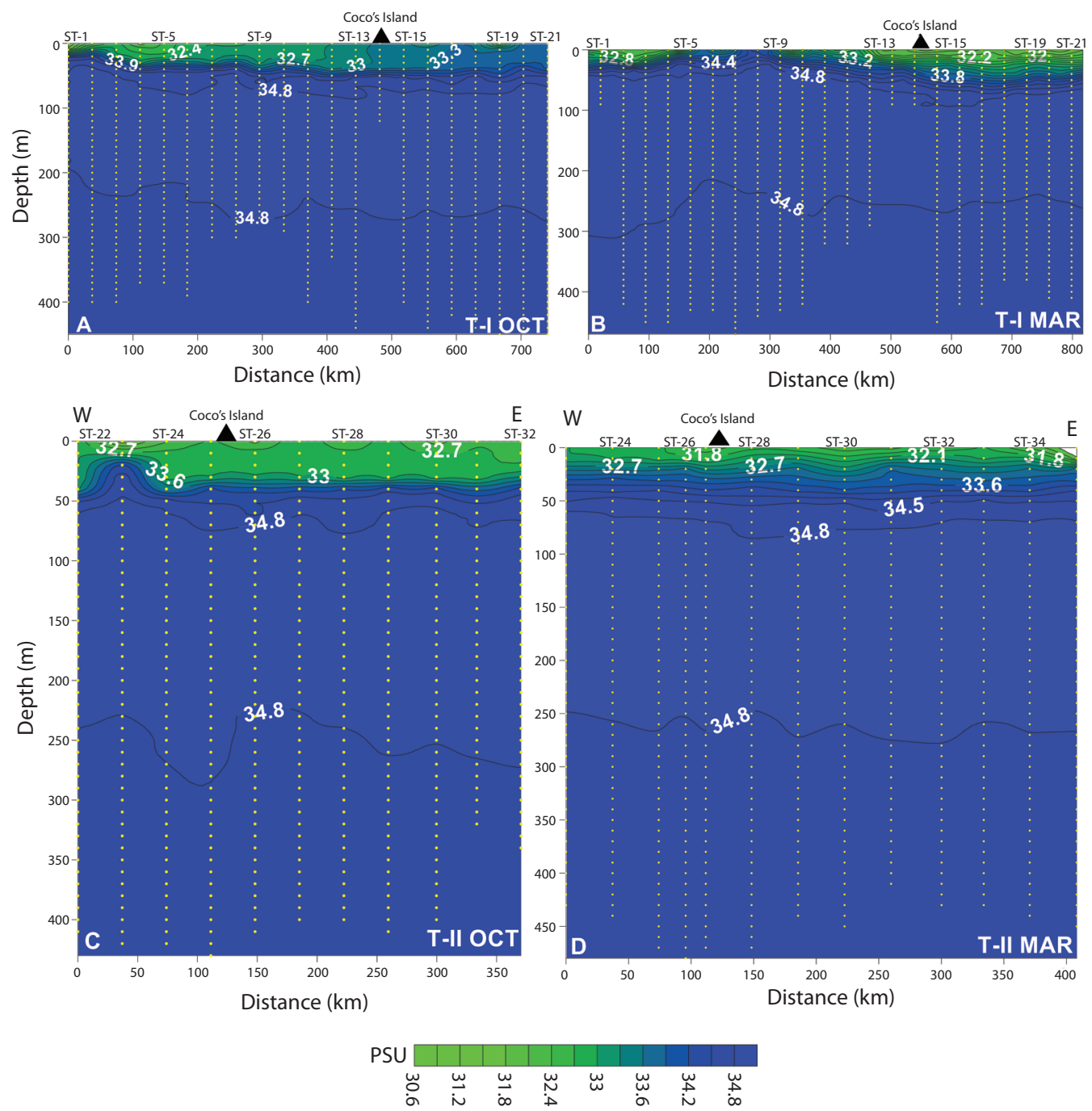

Fig. 3. Vertical distribution of salinity (PSU), for the months of October 2010 (A) Transect I, (C) Transect II, and March 2011 (B) Transect I, (D) Transect II.

Fig. 3. Distribuciones verticales de salinidad (PSU), para los meses de octubre del 2010 (A) Transecto I, (C) Transecto II, y marzo del 2011 (B) Transecto I, (D) Transecto II.

33.2 around Cocos Island in October To the west side of the Island, isohalines also show an upward slope (Fig. 3C) in line with the thermal structure of Figure 2C, evincing the presence of a cyclonic movement below $15 \mathrm{~m}$.

In March the vertical saline field is much less homogeneous in the upper layers than in October. Two low-salinity cores stand out $(\mathrm{S}<32.8)$ in the region close to the coast (stations 1 and 5) and in the area adjacent to Cocos Island (Fig. 3D). To the north of the Island the isohalines slope upwards, and some of them even break the surface between stations 6 and 13. The core of salty waters to the SSW delimited by the isohaline of 34.8 is now located less deeply than in October. Zonal variations of salinity throughout transect II are insignificant, and isohalines were distributed 
by zones, almost parallel to each other (Fig. 3D). Again, Cocos Island is located in a zone of low salinities, with values lower than 31.8.

The T-S diagram (Fig. 4) for the two cruises makes it possible to identify the Tropical Surface Water (TSW), which is at the shallower levels of the water column, with temperatures higher than $25^{\circ} \mathrm{C}$ and salinities lower than 33, as well as the Subsurface Subtropical Water, characterized by a highly salty core close to 35 .

The analysis of vertical geostrophic velocity fields for October makes it possible to detect the presence of a component of the flow predominantly towards the southeast (Fig. 5A) in transect I between Cocos Island and the continent, except for some patches with relatively slow velocities in the opposite direction. It was not possible to detect any northwards flow close to the continent which could be linked to the Costa Rica Coastal Current (CRCC). The SE movement reached its greatest intensity in the first $50 \mathrm{~m}$ below the surface, with values above $40 \mathrm{~cm} \mathrm{~s}^{-1}$. To the south of Cocos Island, the direction of the flows is more complex, and showed significant variability.

In October, the geostrophic movement transversal to transect II (Fig. 5B) showed southern flows compatible with a cyclonic eddy (in a counter-clockwise direction) at its western end, consistent with subsurface thermohaline structures in the shape of a dome (Figs. 2C, 3C). The flow throughout the whole transect showed alternating direction to the north and south, including a rapid movement $\left(60 \mathrm{~cm} \mathrm{~s}^{-1}\right)$ northwards in the first $50 \mathrm{~m}$ of the water column at the eastern end of the section. In October, Cocos Island appears to be immersed in an anti-cyclonic movement (in a clockwise direction) with a diameter of approximately $100 \mathrm{~km}$, and surface velocities between $10 \mathrm{~cm} \mathrm{~s}^{-1}$ and $20 \mathrm{~cm} \mathrm{~s}^{-1}$ extending down to 150 $\mathrm{m}$ beneath the surface (Fig. 5A). The vortex

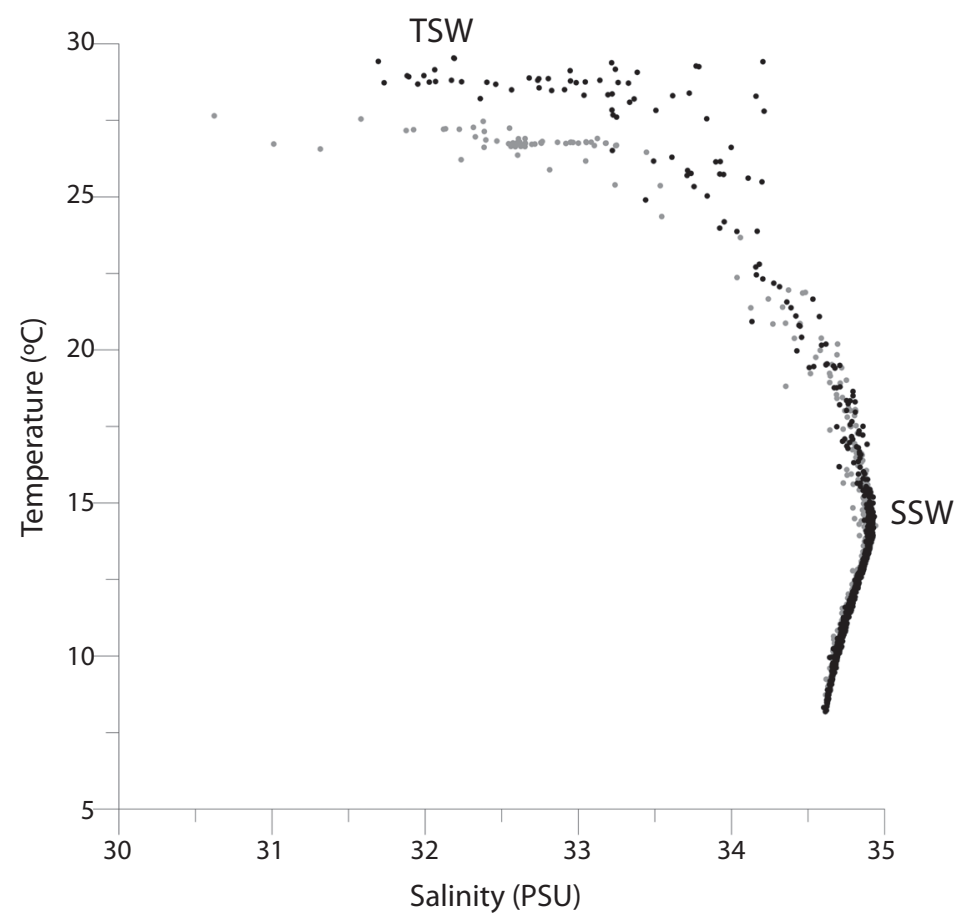

Fig. 4. T-S dispersion diagram for October (light gray) and March (black). Fig. 4. Diagrama T-S dispersivo para octubre (gris claro) y marzo (negro). 


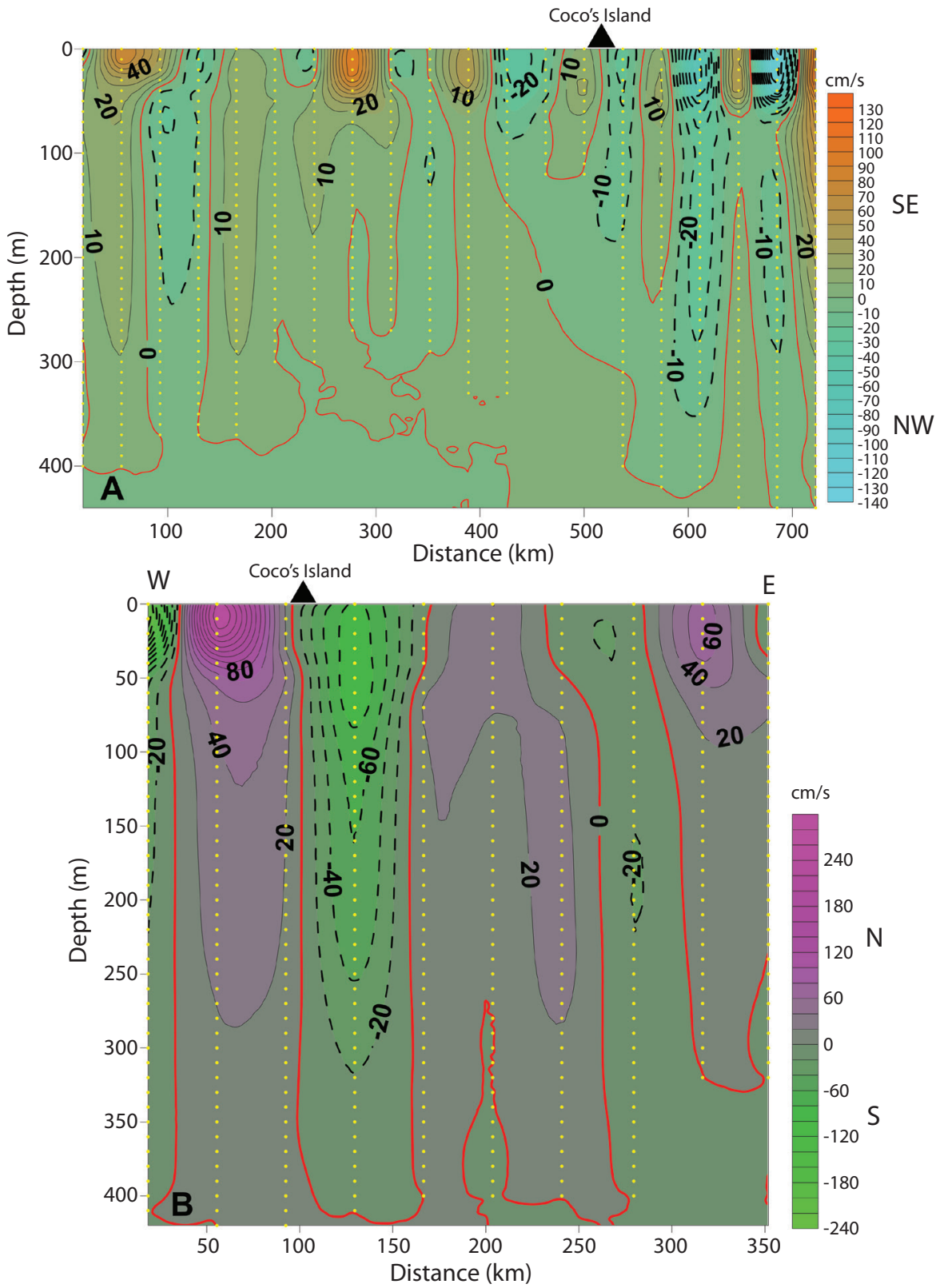

Fig. 5. Vertical distribution of geostrophic velocity $\left(\mathrm{cm} \mathrm{s}^{-1}\right)$ in October 2010, for the transect I (A) and transect II (B).

Fig. 5. Distribuciones verticales de la velocidad geostrófica $\left(\mathrm{cm} \mathrm{s}^{-1}\right)$ en octubre 2010, para el transecto I (A) y el transecto II (B).

which seems to surround Cocos Island appears to be much better defined in its southern movement, reaching down to $300 \mathrm{~m}$ (Fig. 5B).

In March, geostrophic observations show several differences with respect to the conditions in October. Transect I of March (Fig. 6A), from the coast towards Cocos Island, shows a NW flow beyond the continental shelf parallel to the coast, extending about $200 \mathrm{~km}$ and reaching a depth of $300 \mathrm{~m}$ at its most 

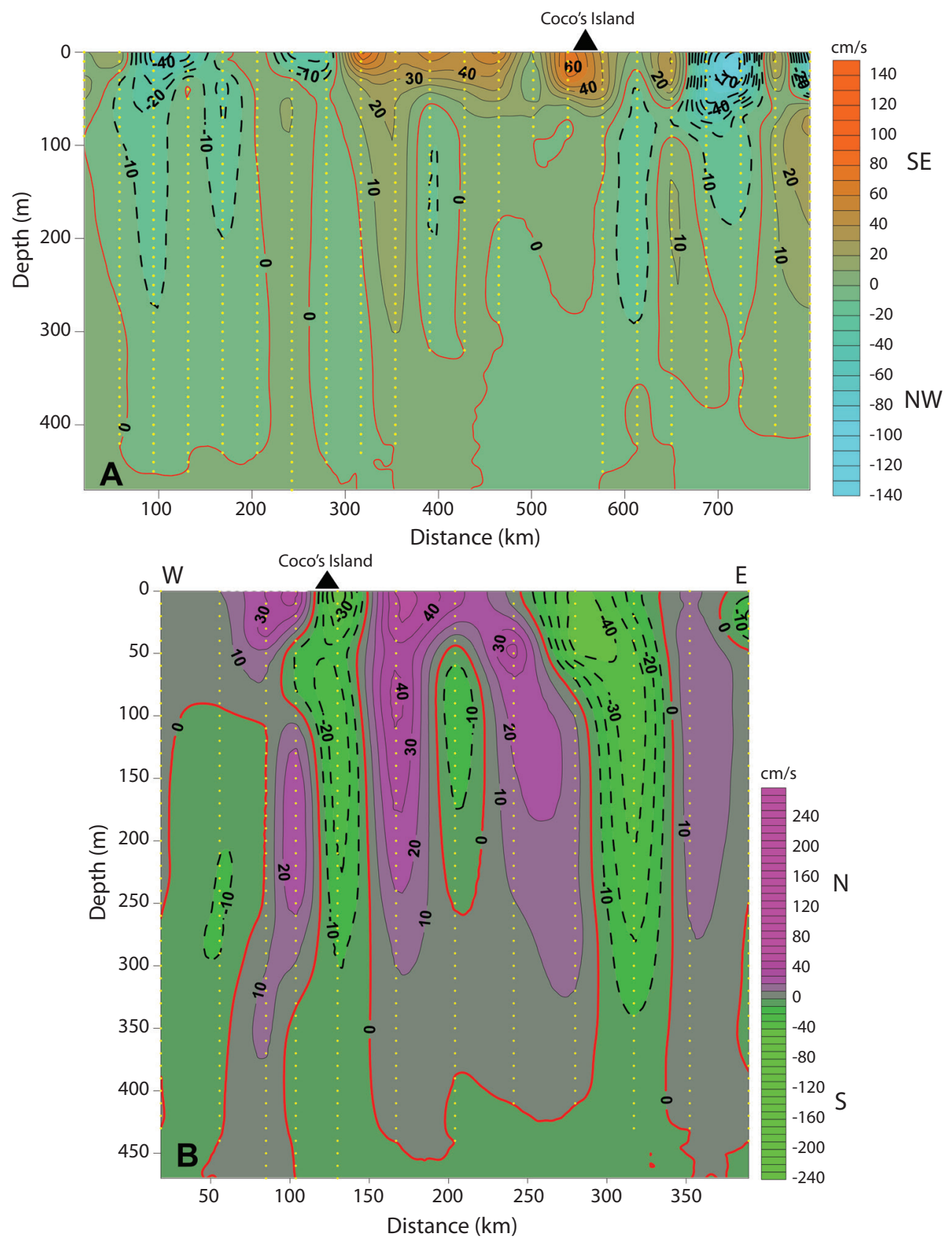

Fig. 6. Vertical distribution of geostrophic velocity $\left(\mathrm{cm} \mathrm{s}^{-1}\right)$ in March 2011, for the transect I (A) and transect II (B).

Fig. 6. Distribuciones verticales de la velocidad geostrófica $\left(\mathrm{cm} \mathrm{s}^{-1}\right)$ en marzo 2011, para el transecto I (A) y el transecto II (B).

intense core close to the continent, with velocities greater than $20 \mathrm{~cm} \mathrm{~s}^{-1}$ above $70 \mathrm{~m}$. Near the coast the currents are reversed, and there is flow towards the SE with speeds between
$10 \mathrm{~cm} \mathrm{~s}^{-1}$ and $20 \mathrm{~cm} \mathrm{~s}^{-1}$, just at the edge of the continental shelf, probably dominated by the astronomical tide which is known to flow in this direction (Murillo,1990) during the ebb 
tide prevalent at sampling time in these locations. Further to the southwest the flow that crosses the section is towards the SE, with speeds greater than $40 \mathrm{~cm} \mathrm{~s}^{-1}$ in the upper $40 \mathrm{~m}$, extending to around $100 \mathrm{~km}$ to the southeast of Cocos Island. In the last part of the transect, a flow towards the NW was observed with intensities greater than $40 \mathrm{~cm} \mathrm{~s}^{-1}$ above $60 \mathrm{~m}$, followed by flow towards the SE of $10-20 \mathrm{~cm} \mathrm{~s}^{-1}$.

The zonal transect (T-II, Fig. 6B) of March 2011 shows less intense southern flows than those observed in October 2010 (Fig. 5B). Cocos Island appears on the southern flank of an anticyclonic structure about $250 \mathrm{~m}$ deep, with a horizontal scale of less than $150 \mathrm{~km}$ and a velocity of $20 \mathrm{~cm} \mathrm{~s}^{-1}$. More southern anticyclonic flow was observed to the east, on a greater horizontal scale $(>300 \mathrm{~km})$ and with a speed of $40 \mathrm{~cm} \mathrm{~s}^{-1}$ in the upper $50 \mathrm{~m}$ of the water column, extending again down to $250 \mathrm{~m}$ depth.

Figure 7 shows the weekly geostrophic velocity vectors at the surface corresponding to the sampling periods, derived from MADT altimetry data (AVISO, 2014). From October 4 through 10 , to the east of $120^{\circ} \mathrm{W}$, a meandering surface flow of the NECC could be observed (Fig. 7A), entering into the region at $9^{\circ} \mathrm{N}$ and moving its axis southwards throughout its trajectory. During this period, Cocos Island was located at the southern end of the NECC, which intensified at its eastern extreme but without reaching the coasts of the Isthmus. Note that towards the west of Galapagos Islands, the intense South Equatorial Current (SEC) flowed to the west between the equatorial line and $4^{\circ} \mathrm{N}$.

In March, the map of surface geostrophic velocities (Fig. 7B) shows a different situation than that in Figure 7A. During this period, with the Inter-Tropical Convergence Zone (ITCZ) located at its southernmost latitude of the year, there was no evidence of a defined NECC entering the region from the west, and to the north of $6^{\circ} \mathrm{N}$ the circulation was dominated by anticyclonic eddies induced by the Papagayo and Tehuantepec wind-jets (four clearly defined eddies are visible), a feature prevalent in the ETP from November to
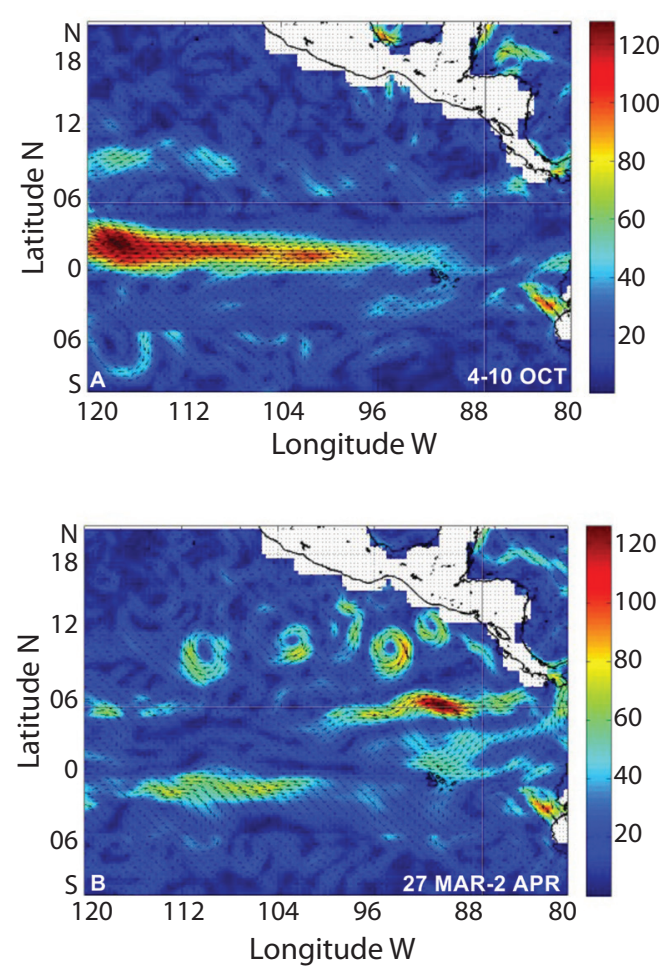

Fig. 7. Weekly average of surface geostrophic velocities for October 4-10 $2010\left(\mathrm{~cm} \mathrm{~s}^{-1}\right)$ (A), and March 27-April 2 2011 (B). The altimeter products were produced by Ssalto/ Duacs and distributed by AVISO, with support from Cnes. The white lines of latitude and longitude intersect at the Cocos Island.

Fig. 7. Promedio semanal del 4-10 octubre 2010 de las velocidades geostróficas superficiales $\left(\mathrm{cm} \mathrm{s}^{-1}\right)$ (A) y del 27 marzo-2 abril 2011 (B). Los productos de altimetría fueron generados por Ssalto/Duacs y distribuidos por AVISO, con el apoyo de Cnes. La Isla del Coco está ubicada en la intersección de las líneas blancas.

April (eg. Hansen, \& Maul, 1991; Ballestero, \& Coen, 2004; Kessler, 2006). The SEC disappeared and the equatorial belt is now occupied by a westward flow extending approximately to $100^{\circ} \mathrm{W}$. To the east of $100^{\circ} \mathrm{W}$ an intense zonal flow is observed towards the continent with southern northwards and southwards extensions, centered at $6^{\circ} \mathrm{N}$, which surrounds the Cocos Islands with surface velocities between $40 \mathrm{~cm} \mathrm{~s}^{-1}$ and $60 \mathrm{~cm} \mathrm{~s}^{-1}$, and in its last stages of approaching the continent turns towards the NE. There are signs that this circulation bifurcates when it reaches the continental slope into 
two branches aimed towards the NW and SE, with the latter being better well-defined. A flow parallel to the coast, consistent with the CRCC, is observed towards the northeast, interacting with the eddy in front of the Gulf of Fonseca, which has been previously reported by several authors for this period (Hansen, \& Maul, 1991; Ballestero, \& Coen, 2004; Brenes et al., 2008). The most intense part of the zonal flow that reaches Cocos Island from the west appears as the north flank of a large anticyclonic vortex which reaches to the south as far as the Galapagos Islands, and the southern edge of this circulation appears to be fed by the large filament generated by the Panama jet.

\section{DISCUSSION}

Hydrography and circulation in the Eastern Tropical Pacific are strongly affected by interactions between the ocean and the atmosphere. There is a seasonal signal in most oceanographic characteristics of the zone studied associated with the north-south migration of the InterTropical Convergence Zone (ITCZ).

Surface temperatures above $27^{\circ} \mathrm{C}$ found in both transects during the months when samples were taken (Fig. 2) were within the expected range for the area being studied, known as the "Eastern Pacific Warm Pool". In this region, surface temperatures are higher than $27^{\circ} \mathrm{C}$ throughout the year, except in the areas under the influence of seasonal upwellings of the Gulf of Tehuantepec, Gulf of Papagayo and Gulf of Panamá, or of the oceanic upwelling of the CRTD (Fiedler, 2002; Xie, Haiming, Kessler, \& Masami, 2005; Fiedler, \& Talley, 2006).

The higher temperatures observed in March are due to the fact that the annual cycle of the surface thermal field in this region reaches its peak between March and May, with deviations of around $1{ }^{\circ} \mathrm{C}$, while from September through November these deviations reach $-0.5^{\circ} \mathrm{C}$ relative to the climatologic value $\left(27^{\circ} \mathrm{C}\right)$. In addition to relatively high surface temperatures, this region has a shallow mixed layer (ML) of around 30m or less (Fiedler, 1992). This feature may also be observed in Figure 2, in which the surface isothermal layer appears thinner near the continent in the sampling periods $(\sim 20 \mathrm{~m})$.

In both cruises, the thermocline, defined on the position of the $20^{\circ} \mathrm{C}$ isotherm, is located between $40 \mathrm{~m}$ and $60 \mathrm{~m}$ deep, consistent with Fiedler's findings (1992). In the two months when samples were taken (Figs. 2A, B) an upward slope towards the continent was observed in the thermocline at the north of Cocos Island, while to the south of the Island it deepened reaching $70 \mathrm{~m}$ (Fig. 2B, station 18) at the end of the transect.

The zonal position of the thermocline in transect II (Fig. 2C, D) is very stable in both samples $(\sim 50 \mathrm{~m})$, except for the structure in the shape of a dome which was observed in October between stations 22 and 24 (Fig. 2C), where it rose to a depth of less than $30 \mathrm{~m}$. This rise in isotherms did not reach the surface and appears to be the result of a surface cyclonic eddy. In general, the mixed layer (identified here as the isothermal surface layer) depth showed spatial patterns very similar to those of the thermocline depth.

The southeast of the Central American Pacific is characterized by surface salinities lower than 33. During this investigation, salinity levels of 32 and 33.2 were found (Fig. $3 \mathrm{~A}, \mathrm{~B})$. In October, the lowest salinities were located near the continent between stations one and five (Fig. 3A), when the ITCZ approached its northernmost position, exerting an influence throughout the Central American Isthmus, while in March they were observed surrounding and to the south of Cocos Island, between stations thirteen and nineteen (Fig. 3B). During this period the ITCZ was near its southernmost position. These results are in line with the analysis by Fiedler (1992) of spatiotemporal deviations of this variable in these months.

In the first transect, the halocline was very well defined and occupied a location in the water column similar to that of the thermocline ( $\sim 50 \mathrm{~m})$ (Fig. 3A, B). In March, isohalines broke the ocean's surface, rising from $30 \mathrm{~m}$ between stations five and nine (Fig. 3B), showing the presence of a very well-defined saline front in this region. 
The T-S diagram of the water masses present in the area under study (Fig. 4) shows, as expected, greater dispersion in the TSW indices due to a temperature increase which was observed in March compared to the temperature observed in October. Below the mixed layer, the water masses show less seasonal variation, and the T-S diagrams perfectly fit near the salty core of the SSW.

The analysis of current fields should take into account that to the east of $120^{\circ} \mathrm{W}$ the scenario is highly complex due to the presence of strong southern flows which drain zonal currents flowing towards and away from of the zone being studied (Kessler, 2006). In addition, the NECC, still in its period of maximum intensity (August-December), weakens to the east of the $100^{\circ} \mathrm{W}$.

Zonal geostrophic currents obtained in both months sampled were related to the existence of a circulation pattern similar to the monthly average reported by several authors (Wyrtki,1965; Fiedler, \& Talley, 2006; Kessler, 2006; Brenes et al., 2008, Lizano, 2008), and to maps of geostrophic currents obtained using altimetric data.

During October, the NECC appears as a fairly well-defined eastward flow, which goes from approximately $4^{\circ} \mathrm{N}$ to $9^{\circ} \mathrm{N}$, so that the Cocos Island is surrounded by this zonal flow (Figs. 5A, 7A).

The NECC is the most important eastward flow within the current system of the area under study, and is fed by the currents of the western edge of the north and south. Between May and January it is fed by both hemispheres, and it broadens between $5^{\circ} \mathrm{N}$ and $10^{\circ} \mathrm{N}$. However, in spite of the fact that a small fraction of the NECC's geostrophic component extends to the east of the $110^{\circ} \mathrm{W}$, it cannot reach the Central American coast because most of it is lost towards the south, feeding the Southern Equatorial Current (SEC) which flows westwards (Fig. 7A). Notwithstanding the foregoing, there are still differences in terms of the eastward extension of the NECC, because the results of some Lagrangian derivatives show an eastward flow crossing $110^{\circ} \mathrm{W}$ (Trasviña, \& Andrade, 2002; Kessler 2006).

The geostrophic velocities obtained in the October cruise (Fig. 5), combined with the contemporaneous synoptic image obtained with altimetric data (Fig. 7A), shed some light on characteristics of the NECC and the circulation in the zone of Cocos Island during this time of year. In Figure 5B, the intensity of the southern flows surrounding the Island in what seems to be an anticyclonic eddy stands out. Figure 7A shows two structures to the west and east of the Island, the latter better defined, with an anticyclonic movement. More to the west, Figure 7A shows several ripples in the NECC which are characteristic of an unstable flow, which may give way to the generation of anticyclonic eddies, and Figure 7A shows several structures to the south of the southern excursions of the NECC with these characteristics. Sprintall, Kennan, Kim \& Niller (2009) show the occurrence of anticyclonic eddies on the southern flank of the NECC at $95^{\circ} \mathrm{W}$, resulting from the propagation of unstable tropical waves (Tropical Instability Waves) as a consequence of the interaction between the NECC and the SEC. If the structures found in this study are of the same nature, their occurrence this far to the east would be remarkable. Data obtained in this cruise, gathered in a single zonal transect (T-II) and a SW-NE transect (T-I), do not provide additional support for this hypothesis, and no contemporaneous satellite derived SST data were available to further investigate it.

Another interesting aspect to analyze is the presence or absence of the CRCC in October. To date there has been a controversy regarding the area where this current starts. According to Wyrtki (1965), its origin is associated with the northward deflection the NECC experiences in the area where the CRTD is. Its beginnings in this area are also discussed in the analyses of Fiedler (2002), Kessler (2002, 2006) and more recently, in those of Brenes et al. (2008). Figure 7A shows an intensification of the NECC to the south of the CRTD, towards the continent, suggesting that the last extension of the current is the southern flank of the cyclonic circulation 
of the CRTD. Transect I of our work is located in the southeast of the eastern extreme of the CRTD, and just as in the present study, Trasviña \& Andrade (2002) did not find evidence that the CRCC was present in this zone during September-October.

As had already been reported by Kessler (2006), and commented in the previous section, zonal geostrophic currents in this area are eroded by the presence of southern flows. This characteristic of the regional circulation pattern may be observed in Figure 5B. Two interesting aspects stand out: on the one hand, what seems to be a very strong cyclonic structure in the western end of transect II (Fig. 5B) with surface velocities higher than $100 \mathrm{~cm} \mathrm{~s}^{-1}$ and extending to $300 \mathrm{~m}$ below the surface, and on the other hand, the anticyclonic flow centered on Cocos Island, weaker and shallower, with velocities of around $20 \mathrm{~cm} \mathrm{~s}^{-1}$, extending down to $150 \mathrm{~m}$ below the surface. Therefore, in October the Island is surrounded by a flow coming from the west, but there is also an anticyclonic cell around it, which may have important impacts on the transportation of larvae and nutrients during this period (Ichii et al., 2002).

In the second oceanographic cruise (MarchApril), the circulation pattern was very different. Between February and April, the northwest monsoon prevents the southern Equatorial Current (SEC) from feeding the NECC, which is therefore fed only by the Northern Equatorial Current (NEC). In this period circulation is limited to the range between $4^{\circ} \mathrm{N}$ and $6^{\circ} \mathrm{N}$, and disappears to the east of $110^{\circ} \mathrm{W}$, where cyclonic and anticyclonic gyres are frequent (Hsin, \& Qiu, 2012).

The Cocos Island is surrounded by a system of eastward currents (Figs. 6A, 7B) with an extension close to $300 \mathrm{~km}$, which is part of a large anticyclonic flow previously reported by several authors (Trasviña, \& Andrade, 2002; Kessler, 2006; Lizano, 2008), and is apparent in Figure 7B. The intensities of the surface current field towards the east are higher than $40 \mathrm{~cm} \mathrm{~s}^{-1}$ and extend to $300 \mathrm{~m}$ below the surface at their northern extreme, and to $100 \mathrm{~m}$ below the surface at their southern end. Part of the southern branch of this circulation with westward currents may be observed $200 \mathrm{~km}$ south of Cocos Island, where a flow towards the northeast stands out, with velocities higher than $50 \mathrm{~cm}$ $\mathrm{s}^{-1}$ in the near surface layers, extending down to $200 \mathrm{~m}$ below the surface (Fig. 6A). A flow towards the NW is visible in this same figure, near the edge of the continental shelf (T-I), with surface velocities of around $40 \mathrm{~cm} \mathrm{~s}^{-1}$.

In March, transect II (Fig. 6B) had a length of more than $400 \mathrm{~km}$, and its west-east orientation made it possible to obtain information about the southward (in the eastern part of the transect) and northward (western part of the transect) flows, which would be part of the anticyclonic circulation in which the Cocos Island is located. Two hundred $\mathrm{km}$ to the east of the Island, a southward flow dominates the area, with velocities of $40 \mathrm{~cm} \mathrm{~s}^{-1}$ on the surface, extending to almost $300 \mathrm{~m}$ below the surface. To the west of the Island, the currents flow to the north with velocities of around $20 \mathrm{~cm} \mathrm{~s}^{-1}$, reaching a depth close to that of the previously mentioned flow.

The most outstanding aspect of the March cruise is that, in spite of the absence of a NECC entering the region from the Central Pacific (Fig. 7B), Cocos Island was under the influence of an intense western-eastern zonal geostrophic current that in its final leg rotates towards the NE, heading towards southern Costa Rica. Although Figure 7B shows important southward extensions of this current, measurements obtained in the zonal transect (T-II) do not show southern flows as intense as those of October. Again, having a single zonal transect does not allow reaching definite conclusions about the southern movement during this period of the year. Figure $7 \mathrm{~B}$ suggests that the intense eastwards flow at $6^{\circ} \mathrm{N}-90^{\circ} \mathrm{W}$ bifurcates before reaching Cocos Island: one part rotates southward to join the great anticyclonic gyre discussed in previous paragraphs, while most of the current continues eastward, passing Cocos Island before it finally makes a NE turn towards the continent. It is important to emphasize that both hydrographic and altimetric measurements (Figs. 6A, 7B), show 
the existence of a NW-bound current during March-April 2011, parallel to the continent between the coast and the CRTD, which is consistent with the characteristics of the CRCC (Brenes et al., 2008).

Finally, the surface current fields obtained in the present investigation (Figs. 5, 6) and those deducted from altimetric data (Fig. 7) show a strong congruence: the flow of the NECC present in October encompassing a great portion of the area studied, and in March an anticyclonic gyre modulating the regional dynamics. In both of these periods Cocos Island is directly affected by currents from the west.

The results complement those reported in previous studies and added details to aspects of scientific relevance, such as the behavior of the NECC when it reaches its eastern border. These later aspect could be used in the future to explain some biological processes of interest, such as transport of larvae in the area of influence of the Cocos Island.

\section{ACKNOWLEDGMENTS}

This work was carried out as part of the Project (808-B0-654) "Interacción océanoatmósfera y la biodiversidad marina del Parque Nacional Isla del Coco, Costa Rica" (Sea-Air Interaction and marine biodiversity of the Cocos Island National Park, Costa Rica), carried out by the Universidad de Costa Rica and the Universidad Nacional with funds from the National Council of Rectors (CONARE). We would like to thank Jorge Cortés from the Centro de Investigación en Ciencias del Mar y Limnología (CIMAR), for his comments and observations on our manuscript. Thanks to the Dirección de Investigación of the Universidad Nacional, who partially financed the publication of this work through the "Fondo para el apoyo a la divulgación del conocimiento generado en la UNA".

\section{RESUMEN}

El presente estudio se desarrolló en la región sureste del Pacífico Centroamericano, una zona de gran importancia oceanográfica debido a la presencia de diversos fenómenos de afloramiento y a la influencia directa del Fenómeno ENOS sobre sus aguas. Su objetivo principal fue contribuir al conocimiento de los principales factores que modulan la dinámica regional. Se describe la circulación geostrófica y las características termohalinas en dos transectos obtenidos en octubre de 2010 y marzo de 2011, uno de Costa Rica desde (84 $\left.54^{\prime} \mathrm{W}-9^{\circ} 37^{\prime} \mathrm{N}\right)$ hasta el SO de la Isla del Coco en $\left(88^{\circ} 19^{\prime} \mathrm{W}-3^{\circ} 06^{\prime} \mathrm{N}\right)$, y el segundo orientado zonalmente a través de la isla a partir de $\left(88^{\circ} 14^{\prime} \mathrm{W}-5^{\circ} 33^{\prime} \mathrm{N}\right)$ hasta $\left(84^{\circ} 33^{\prime} \mathrm{W}-5^{\circ} 33^{\prime} \mathrm{N}\right)$. Las temperaturas superficiales oscilaron entre $27^{\circ} \mathrm{C}$ y $29^{\circ} \mathrm{C}$ y una capa isotérmica con un espesor medio de $40 \mathrm{~m}$, era evidente por encima de la termoclina centrada en $60 \mathrm{~m}$. Las salinidades superficiales estuvieron entre 32 y 32.8, valores típicos del Agua Superficial Tropical. En ambos años, la Isla del Coco se encuentra en una región de salinidades superficiales bajas $(\sim 32)$. El núcleo de alta salinidad del Agua Subsuperficial Subtropical ( 35) se localizó a una profundidad media de $150 \mathrm{~m}$. En octubre, la circulación entre la Isla del Coco y el continente estuvo dominada por la presencia de la Contracorriente Ecuatorial Norte (NECC), con velocidades superiores a $40 \mathrm{~cm} \mathrm{~s}^{-1}$ por encima de los $50 \mathrm{~m}$ de la columna de agua. En octubre no se observó ningún flujo hacia el noroeste, cerca de la costa que pudiera estar asociado con la Corriente Costera de Costa Rica (CCCR). La Isla del Coco estuvo localizada en el centro de un giro anticiclónico de $100 \mathrm{~km}$ de diámetro y $150 \mathrm{~m}$ de profundidad, con velocidades superficiales entre $10 \mathrm{~cm} \mathrm{~s}^{-1}$ y $20 \mathrm{~cm} \mathrm{~s}^{-1}$. En marzo el área estudiada es dominada por una circulación anticiclónica. Parte de los flujos hacia el este de dicho giro se localizaron a partir de $200 \mathrm{~km}$ al norte y hasta $100 \mathrm{~km}$ al sur de la Isla del Coco, con intensidades entre $50 \mathrm{~cm} \mathrm{~s}^{-1}$ y $60 \mathrm{~cm} \mathrm{~s}^{-1}$. El extremo sur de esta celda, con velocidades entre $10 \mathrm{~cm} \mathrm{~s}^{-1}$ y $50 \mathrm{~cm} \mathrm{~s}^{-1}$ hacia el noroeste, se encuentra a $200 \mathrm{~km}$ al sur de la Isla del Coco. Un flujo hacia el NW cerca del borde de la plataforma continental, en correspondencia con la CCCR, se observó en mayo. Nuestro estudio contribuye a documentar la oceanografía del extremo oriental del Sistema Corrientes Ecuatoriales, cerca de la costa de América Central, donde forzamientos regionales modifican los flujos zonales que prevalecen al oeste de la zona de estudio.

Palabras clave: Circulación geostrófica, Contracorriente Ecuatorial Norte, Isla el Coco, masas de agua.

\section{REFERENCES}

AVISO (2014). SSALTO/DUACS User Handbook: (M) SLA and (M) ADT Near-Real Time and Delayed Time Products, CLS-DOS-NT-06-034. Paris, France: Centre National d'Études Spatiales.

Amador, J., Alfaro, E., Lizano, O., \& Magaña, V. (2006). Atmospheric forcing in the Eastern Tropical Pacific: A Review. Progress in Oceanography, 69, 101-142. 
Ballestero, D., \& Coen, J. (2004). Generation and propagation of anticyclonic rings in the Gulf of Papagayo. International Journal of Remote Sensing, 25, 2217-2224.

Brenes, C. L. (1983). Condiciones de Movimiento Geostrófico en el área del Domo Térmico de Costa Rica. Ciencia y Tecnología, 7(1), 121-152.

Brenes, C., Lavín, M., \& Mascarenhas, A. (2008). Geostrophic circulation between the Costa Rica Dome and Central America. Deep-Sea Research I, 55, 608-629.

Chelton, D. B., DeSzoeke, R. A., Schlax, M. G., Naggar K. E., \& Siwertz, N. (1998). Geographical variability of the first baroclinic Rossby radius of deformation. Journal of Physical Oceanography, 28, 433-460.

Chelton, D., Schlax, M., Freilich, M., \& Milling, R. (2004). Satellite measurements reveal persistent small-scale features in ocean winds. Science, 303, 978-983.

Díaz, J., \& Neshyba, S. (1985). Manifestaciones de El Niño 1982-1983 en el trayecto Nicoya - Isla de El Coco. Uniciencia, 2(1), 53-56.

Fiedler, P. (1992). Seasonal climatologies and variability of Eastern Tropical Pacific surface waters. NOAA Technical Report NMFS 109, 70 pp.

Fiedler, P. (2002). The annual cycle and biological effects of the Costa Rica Dome. Deep-Sea Research I, 49, 231-338.

Fiedler, P., \& Talley, L. (2006). Hydrography of the eastern Pacific: a review. Progress in Oceanography, 69, 143-180.

Hansen, D., \& Maul, G. (1991). Anticyclonic current rings in the eastern tropical Pacific Ocean. Journal of Geophysical Research, 96, 6965-6979.

Hsin, Y., \& Qiu, B. (2012). Seasonal fluctuations of the surface North Equatorial Countercurrent (NECC) across the Pacific basin. Journal of Geophysical Research, 117, 1-17.

Ichii, T., Mahapatra, K., Watanabe, T., Yatsu, A., Inagake, D., \& Okada, Y. (2002). Occurrence of jumbo flying squid Dosidicus gigas aggregations associated with the countercurrent ridge o the Costa Rica Dome during 1997 El Niño and 1999 La Niña, Marine Ecology Progress Series, 231, 151-166.
Kessler, W. (2002). Mean three-dimensional circulation in the northeast tropical Pacific. Journal of Physics Oceanography, 32, 2457-2471.

Kessler, W. (2006). The circulation of the Eastern Tropical Pacific: a review. Progress in Oceanography, 69, 181-217.

Lizano, O. (2008). Dinámica de aguas alrededor de la Isla del Coco, Costa Rica. Revista de Biología Tropical, 56(Supplement 2), 31-48.

Murillo, L. M. (1990). La circulación de las Mareas en el Golfo de Nicoya. Tecnología en Marcha, 10(4), 51-76.

Sprintall, J., Kennan, S., Kim, Y., \& Niller, P. (2009). Wind-Driven ageostrophic transport in the North Equatorial Countercurrent of the eastern Pacific at $95^{\circ}$ W. Journal of Physical Oceanography, 39, 2985-2998.

Trasviña, A., \& Andrade, C. (2002). Circulación Costera del Pacífico Tropical Oriental, con énfasis en la Cuenca Cálida Mexicana. En Circulación oceánica y climatología tropical en México y Colombia. Diálogo entre Pares 1 (pp. 9-37). Bogotá, Colombia: Consejo Nacional de Acreditación - Ministerio de Educación, Corcas.

Tsuchiya, M. (1975). Subsurface countercurrents in the eastern equatorial Pacific. Journal of Marine Research, 33(1), 145-175.

Tsuchiya, M., \& Talley, L. (1998). A Pacific hydrographic section at $88^{\circ} \mathrm{W}$ : water-property distribution. Journal of Geophysical Research, 103, 12899-12918.

Wyrtki, K. (1965). Surface currents of the eastern tropical Pacific Ocean. Inter-American Tropical Tuna Commission Bulletin, 9(5), 271-304.

Wyrtki, K. (1966). Oceanography of the Eastern equatorial Pacific Ocean. Oceanography and Marine Biology: Annual Review, 4, 33-68.

Xie, S., Haiming, X., Kessler, W., \& Masami, N. (2005). Air-sea interaction over the Eastern Pacific Warm Pool: Gap winds, thermocline dome, and atmospheric convection. Journal of Climate, 18, 5-20. 